\title{
Structural Elucidation and Bioactivity of Biflavonoids from the Stems of Wikstroemia taiwanensis
}

\section{Li-Yin Chen ${ }^{1}{ }^{*}$, Ih-Sheng Chen ${ }^{2}$ and Chien-Fang Peng ${ }^{3}$}

1 Department of Pharmacy, Chia-Nan University of Pharmacy and Science, Tainan 71710, Taiwan

2 School of Pharmacy, College of Pharmacy, Kaohsiung Medical University, Kaohsiung 80708, Taiwan; E-Mail: m635013@kmu.edu.tw

3 Department of Medical Laboratory Science and Biotechnology, College of Health Sciences, Kaohsiung Medical University, Kaohsiung 80708, Taiwan; E-Mail: chfape@kmu.edu.tw

* Author to whom corresponding should be addressed; E-Mail: eijodesu @ mail.chna.edu.tw; Tel.: +886-6-266-4911 ext. 2209; Fax: +886-6-266-7318.

Received: 6 December 2011; in revised form: 1 January 2012 / Accepted: 10 January 2012 / Published: 18 January 2012

\begin{abstract}
Three new biflavonoids, wikstaiwanones A-C (1-3), along with four known compounds (4-7) were isolated from the stems of Wikstroemia taiwanensis (Thymelaeaceae). Their structures were elucidated by spectroscopic analysis. Compounds 4 and $\mathbf{5}$ showed antitubercular activity against Mycobacterium tuberculosis with MIC values of $15 \mu \mathrm{g} / \mathrm{mL}$, respectively.
\end{abstract}

Keywords: Wikstroemia taiwanensis; Thymelaeaceae; stem; biflavonoid; antitubercular activity

\section{Introduction}

Tuberculosis (TB), including multidrug resistant tuberculosis and extensively drug resistant tuberculosis, remains an epidemic in many regions of the world, with an estimated 8.8 million new cases and caused 1.1 million deaths globally in 2010 [1]. In Taiwan, it is also one of the most important communicable infectious diseases subject to official notification, with the highest number of confirmed cases and deaths [2]. Searching new sources of antitubercular agents from nature is crucial to curb the rise of drug-resistant strains. Examining an antitubercular activity from crude extracts of several Taiwan endemic plants, we found the methanolic extract of the stems of 
Wikstroemia taiwanensis showed potent activity against Mycobacterium tuberculosis $\mathrm{H}_{37} \mathrm{Rv}$ in vitro W. taiwanensis (Thymelaeaceae) is an endemic deciduous shrub growing in the south of Taiwan. Analysis of the chemical constituents and bioactivity of this plant has not been conducted previously. Bioactivity-directed fractionation of the active EtOAc layer of the stems of this species led to the isolation and characterization of three biflavonoids, wikstaiwanones $\mathrm{A}-\mathrm{C}(\mathbf{1}-\mathbf{3})$, along with three known biflavonoids, sikokianins B (4) [3], C (5) [4], isochamaejasmin (6) [5], and, methyl 4-hydroxybenzoate (7) [6] (Figure 1). This paper reports the structure elucidation of 1-3 and their antitubercular activities.

Figure 1. Structures of Compounds 1-7.

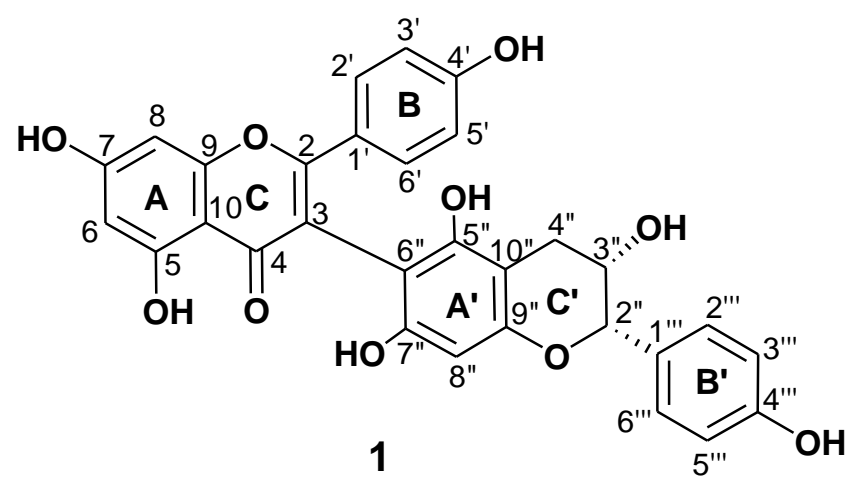<smiles>O=c1c(-c2c(O)cc3c(c2O)[C@@H](O)[C@H](c2ccc(O)cc2)O3)c(-c2ccc(O)cc2)oc2cc(O)cc(O)c12</smiles><smiles>COc1ccc([C@H]2Oc3cc(O)cc(O)c3C(=O)[C@H]2[C@H]2C(=O)c3c(O)[c-]c(O)cc3O[C@H]2c2ccc(O)cc2)cc1</smiles><smiles>COc1ccc([C@H]2Oc3cc(O)cc(O)c3C(=O)[C@H]2C2C(=O)c3c(O)cc(O)cc3O[C@H]2c2ccc(O)cc2)cc1</smiles><smiles>[R7]c1ccc([C@H]2Oc3cc(O)cc(O)c3C(=O)[C@@H]2C[C@H]2Oc3cc(O)cc(O)c3C(=O)[C@H]2c2ccc(O)cc2)cc1</smiles>

5, $\mathrm{R}=\mathrm{CH}_{3}$

6, $\mathrm{R}=\mathrm{H}$<smiles>COC(=O)c1ccc(O)cc1</smiles>

\section{Results and Discussion}

The present study focused on the fraction of the $W$. taiwanensis stem extract that displayed biological activity, which was confined to the EtOAc-soluble fraction. When this fraction was further separated by gel filtration into four parts, only one of them showed activity against 
Mycobacterium tuberculosis $\mathrm{H}_{37} \mathrm{Rv}$. On separating this active part, compounds 1-7 were isolated, characterization of these compounds indicated 1-3 were new compounds.

\subsection{Structure Elucidation of the New Isolates}

Compound 1 was isolated as an optically active yellowish amorphous powder, $[\alpha]_{\mathrm{D}}^{25}-77.0(c 0.03$, $\mathrm{MeOH}$ ). Its molecular formula was established as $\mathrm{C}_{30} \mathrm{H}_{22} \mathrm{O}_{10}$ by ESI-MS and HR-ESI-MS, with 20 degrees of unsaturation and a dimer composed of a flavone moiety and a flavanol moiety was proposed. The observed UV absorption peaks at 210, $217 \mathrm{sh}, 226,315 \mathrm{sh}$, and $335 \mathrm{sh} \mathrm{nm}$ in conjunction with a bathochromic shift observed after the addition of aq. $\mathrm{KOH}$ suggests the presence of a phenolic flavonoid moiety [7]. The IR spectrum showed absorption bands at $3450 \mathrm{~cm}^{-1}$ for a hydroxy group and at $1647 \mathrm{~cm}^{-1}$ for a carbonyl group. The ${ }^{1} \mathrm{H}$ - and ${ }^{13} \mathrm{C}-\mathrm{NMR}$ spectra (Table 1) of $\mathbf{1}$ showed a trioxygenated flavone moiety [ $\delta_{\mathrm{C}} 160.7(\mathrm{C}-4)$ ), $183.6(\mathrm{C}-4), 163.3(\mathrm{C}-5)$, and $166.0(\mathrm{C}-7)$ ] with two meta-coupled protons $\left[\delta_{\mathrm{H}} 6.18(1 \mathrm{H}, \mathrm{d}, J=2.4 \mathrm{~Hz}, \mathrm{H}-6), 6.32(1 \mathrm{H}, \mathrm{d}, J=2.4 \mathrm{~Hz}, \mathrm{H}-8)\right]$ in ring A and with a para-oxygenated phenyl group $\left[\delta_{\mathrm{H}} 6.67\left(2 \mathrm{H}, \mathrm{d}, J=9.0 \mathrm{~Hz}, \mathrm{H}-3{ }^{\prime}, 5^{\prime}\right), 7.26(2 \mathrm{H}, \mathrm{d}, J=9.0 \mathrm{~Hz}\right.$, $\left.\left.\mathrm{H}-2^{\prime}, 6^{\prime}\right)\right]$ in ring C; and another 4"', 3", 5", 7"-tetraoxygenated flavan moiety $\left(\delta_{\mathrm{C}} 158.1,68.9,154.8\right.$ and $156.0)$ with a para-oxygenated phenyl group $\left[\delta_{\mathrm{H}} 6.70\left(2 \mathrm{H}, \mathrm{d}, J=9.0 \mathrm{~Hz}, \mathrm{H}-3{ }^{\prime \prime}, 55^{\prime \prime}\right), 7.10(2 \mathrm{H}, \mathrm{d}\right.$, $\left.\left.J=9.0 \mathrm{~Hz}, \mathrm{H}-2^{2 \prime}, 6^{\prime \prime \prime}\right)\right]$ in ring $\mathrm{C}^{\prime}$ and an aromatic proton $\left[\delta_{\mathrm{H}} 6.04(1 \mathrm{H}, \mathrm{s}), \mathrm{H}-8^{\prime \prime}\right]$ in ring A'. The HMBC spectrum (Figure 2) showed correlations between the singlet H-8" ( $\left.\delta_{\mathrm{H}} 6.04\right)$ and C-6" $\left(\delta_{\mathrm{C}} 100.7\right)$ and the $\mathrm{H}-3$ in ring $\mathrm{C}$ was lack in flavone moiety. These supported the connection between the flavone moiety and the flavan-3-ol moiety is via C-3 and C-6" linkage. The molecular formula $\mathrm{C}_{30} \mathrm{H}_{22} \mathrm{O}_{10}$ supported the presence of seven hydroxy groups, which were confirmed by ${ }^{13} \mathrm{C}-\mathrm{NMR}$, HMQC, NOESY and HMBC (Figure 2) experiments. The relative configurations of $\mathrm{H}-2$ " and $\mathrm{H}-3$ " were determined by NOESY spectrum, where H-2" showed the correlation with H-3". Comparing with the aglycone levorotatory optical activity of epiafzelechin 5-glucoside $[\alpha]_{\mathrm{D}}^{25}-63(\mathrm{MeOH})[8]$, and the absolute configuration of 1 with $[\alpha]_{\mathrm{D}}^{25}-77.0(c 0.03, \mathrm{MeOH})$ was suggested to be $\left(2 " R: 3^{\prime \prime} R\right)$. It was found that when dissolved in different solvents, other compounds with $(2 " R: 3 " R)$ structure, e.g., (-)-epicatechin [9] and (-)-epigallocatechin [10] also displayed levorotatory optical activity $[9,10]$. Based on the evidence above, the structure of $\mathbf{1}$ was elucidated to be 5,7-dihydroxy-2(4'-hydroxyphenyl)-3-(3" $R, 5$ ",7"-trihydroxy-2" $R$-(4"'-hydroxyphenyl)-3",4"-dihydro-2H-chromen-6"-yl) $-4 H$-chromen-4-one, and named wikstaiwanone A.

Compound 2 was obtained as pale yellowish amorphous powder with $[\alpha]_{\mathrm{D}}^{25}-23.3(c 0.03, \mathrm{MeOH})$. Its molecular formula, $\mathrm{C}_{30} \mathrm{H}_{22} \mathrm{O}_{10}$, was same as $\mathbf{1}$ and established by ESI-MS and HR-ESI-MS. The IR, UV, and NMR (Table 1) spectra of 2 were similar to those of 1, except that the different resonance of H-2" ( $\delta_{\mathrm{H}} 4.53(1 \mathrm{H}, \mathrm{d}, J=8.2 \mathrm{~Hz}), \mathrm{H}-3 "\left(\delta_{\mathrm{H}} 3.68(1 \mathrm{H}, \mathrm{br} \mathrm{d}, J=8.2 \mathrm{~Hz})\right)$ in 2 and $\mathrm{H}-2 "\left(\delta_{\mathrm{H}} 4.13(1 \mathrm{H}, \mathrm{d}\right.$, $J=7.8 \mathrm{~Hz}), \mathrm{H}-3 "\left(\delta_{\mathrm{H}} 3.90(1 \mathrm{H}, \mathrm{ddd}, J=8.4,7.8,6.0 \mathrm{~Hz})\right)$ in $\mathbf{1}$. This proposed 2 is a stereoisomer of $\mathbf{1}$. Referring to the coupling constant $J=8.1 \mathrm{~Hz}$ of $(-)$-catechin with $[\alpha]_{\mathrm{D}}^{25}-14.9$ (c 1.0, 50\% aqueous acetone) [9], $\mathbf{2}$ was suggested to be the 3-epimer of $\mathbf{1}$ and $\mathrm{H}-2 " / \mathrm{H}-3$ " were in trans-orientation. Thus the absolute configuration of $\mathbf{2}$ was determined as $(2 " S: 3 " R)$. Based on the above data, compound 2 was determined to be 5,7-dihydroxy-2-(4'-hydroxyphenyl)-3-(3"R,5",7"-trihydroxy-2" $S$ (4"'-hydroxyphenyl)-3",4"-dihydro-2H-chromen-6"-yl)-4H-chromen-4-one, namely wikstaiwanone B, which was further confirmed by HMQC, DEPT, NOESY, and HMBC (Figure 2) experiments. 
Table 1. ${ }^{1} \mathrm{H}-\mathrm{NMR}$ and ${ }^{13} \mathrm{C}-\mathrm{NMR}$ Data of Compounds $\mathbf{1}$ and 2.

\begin{tabular}{|c|c|c|c|c|}
\hline \multirow[b]{2}{*}{ Position } & \multicolumn{2}{|l|}{$1^{a}$} & \multicolumn{2}{|l|}{$2^{b}$} \\
\hline & $\delta_{\mathrm{H}}(J$ in $\mathrm{Hz})$ & $\delta_{\mathrm{C}}$ & $\delta_{\mathrm{H}}(J$ in $\mathrm{Hz})$ & $\delta_{\mathrm{C}}$ \\
\hline 2 & & 165.0 & & 164.5 \\
\hline 3 & & 114.2 & & 114.4 \\
\hline 4 & & 183.6 & & 183.4 \\
\hline 5 & & 163.3 & & 164.2 \\
\hline 6 & $6.18(\mathrm{~d}, J=2.4 \mathrm{~Hz})$ & 99.9 & $6.18(\mathrm{~d}, J=1.2 \mathrm{~Hz})$ & 99.9 \\
\hline 7 & & 166.0 & & 165.3 \\
\hline 8 & $6.32(\mathrm{~d}, J=2.4 \mathrm{~Hz})$ & 94.6 & $6.38(\mathrm{~d}, J=1.2 \mathrm{~Hz})$ & 94.7 \\
\hline 9 & & 159.5 & & 159.3 \\
\hline 10 & & 105.0 & & 105.7 \\
\hline $1^{\prime}$ & & 126.0 & & 126.4 \\
\hline $2^{\prime}$ & $7.26(\mathrm{~d}, J=9.0 \mathrm{~Hz})$ & 131.4 & $7.57(\mathrm{~d}, J=8.8 \mathrm{~Hz})$ & 131.9 \\
\hline $3^{\prime}$ & $6.67(\mathrm{~d}, J=9.0 \mathrm{~Hz})$ & 115.6 & $6.87(\mathrm{~d}, J=8.8 \mathrm{~Hz})$ & 116.4 \\
\hline $4^{\prime}$ & & 160.7 & & 161.1 \\
\hline $5^{\prime}$ & $6.67(\mathrm{~d}, J=9.0 \mathrm{~Hz})$ & 115.6 & $6.87(\mathrm{~d}, J=8.8 \mathrm{~Hz})$ & 116.4 \\
\hline $6^{\prime}$ & $7.26(\mathrm{~d}, J=9.0 \mathrm{~Hz})$ & 131.4 & $7.57(\mathrm{~d}, J=8.8 \mathrm{~Hz})$ & 131.9 \\
\hline $2^{\prime \prime}$ & $4.13(\mathrm{~d}, J=7.8 \mathrm{~Hz})$ & 82.8 & $4.53(\mathrm{~d}, J=8.2 \mathrm{~Hz})$ & 83.5 \\
\hline 3" & $3.90(\mathrm{ddd}, J=7.8,8.4,6.0 \mathrm{~Hz})$ & 68.9 & $3.68(\mathrm{br} \mathrm{d}, J=8.2 \mathrm{~Hz})$ & 69.2 \\
\hline $4 " \mathrm{a}$ & $2.86(\mathrm{dd}, J=6.0,16.2 \mathrm{~Hz})$ & 29.1 & $2.91(\mathrm{dd}, J=16.0,5.6 \mathrm{~Hz})$ & 30.3 \\
\hline 4"b & $2.46(\mathrm{dd}, J=8.4,16.2 \mathrm{~Hz})$ & & $2.56(\mathrm{dd}, J=16.0,6.8 \mathrm{~Hz})$ & \\
\hline $5 "$ & & 154.8 & & 155.0 \\
\hline $6 "$ & & 100.7 & & 101.0 \\
\hline $7 "$ & & 156.0 & & 156.7 \\
\hline $8^{\prime \prime}$ & $6.04(\mathrm{~s})$ & 96.5 & $6.15(\mathrm{~s})$ & 97.0 \\
\hline 9" & & 157.8 & & 157.7 \\
\hline $10 "$ & & 101.5 & & 101.6 \\
\hline $1 " '$ & & 131.6 & & 131.9 \\
\hline $2^{\prime \prime \prime}$ & $7.10(\mathrm{~d}, J=9.0 \mathrm{~Hz})$ & 129.5 & $6.87(\mathrm{~d}, J=8.8 \mathrm{~Hz})$ & 130.1 \\
\hline $3 " '$ & $6.70(\mathrm{~d}, J=9.0 \mathrm{~Hz})$ & 115.8 & $6.65(\mathrm{~d}, J=8.8 \mathrm{~Hz})$ & 116.2 \\
\hline 4"' & & 158.1 & & 158.5 \\
\hline $5^{\prime \prime \prime}$ & $6.70(\mathrm{~d}, J=9.0 \mathrm{~Hz})$ & 115.8 & $6.65(\mathrm{~d}, J=8.8 \mathrm{~Hz})$ & 116.2 \\
\hline 6"' & $7.10(\mathrm{~d}, J=9.0 \mathrm{~Hz})$ & 129.5 & $6.87(\mathrm{~d}, J=8.8 \mathrm{~Hz})$ & 130.1 \\
\hline
\end{tabular}


Figure 2. Key HMBC Correlations for 1-3.
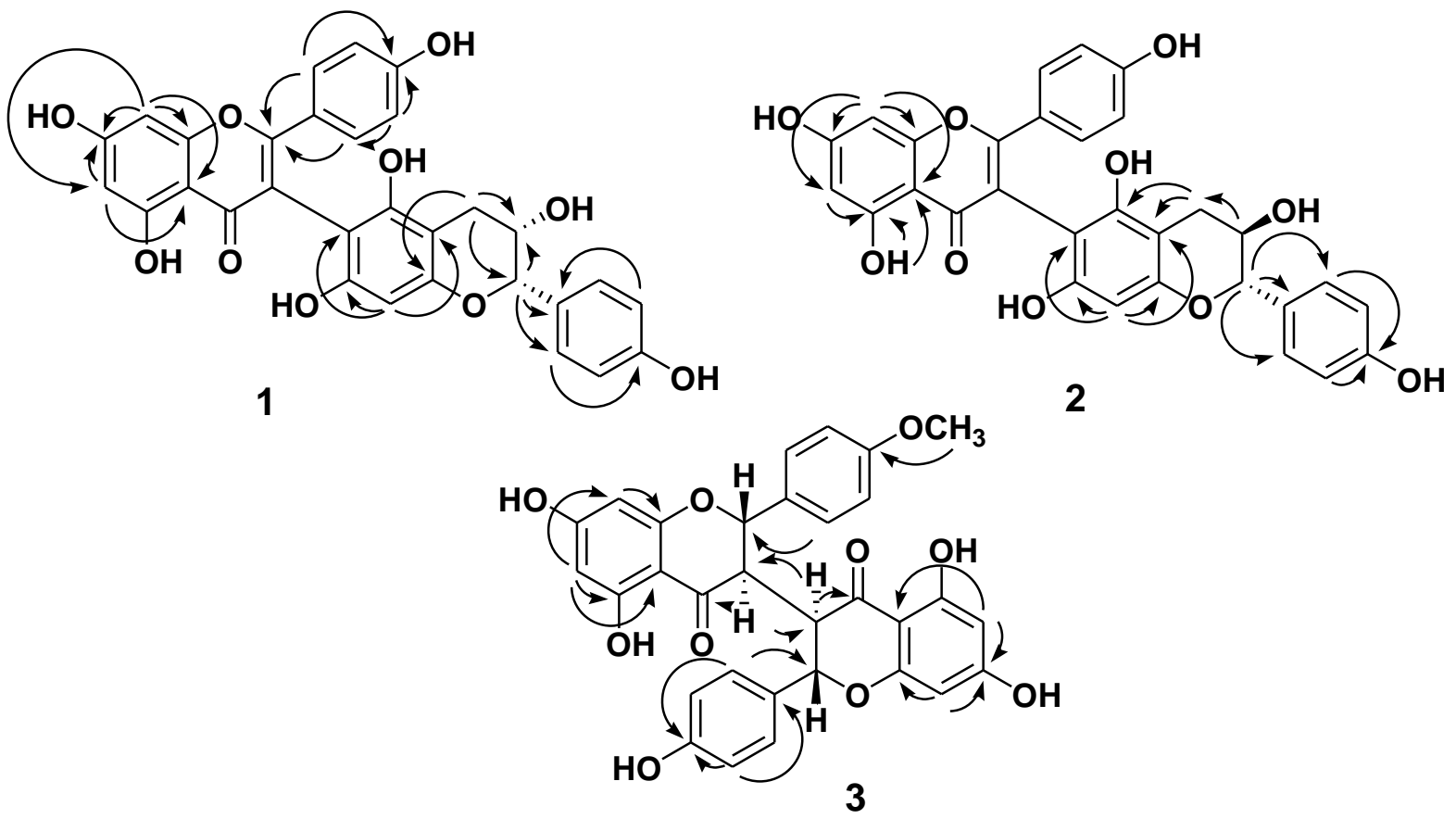

Compound 3 was isolated as pale yellowish amorphous powder with $[\alpha]_{\mathrm{D}}^{25}+53.1(c 0.058, \mathrm{MeOH})$. Its molecular formula was determined as $\mathrm{C}_{31} \mathrm{H}_{24} \mathrm{O}_{10}$ by ESI-MS and HR-ESI-MS with 15 unsaturated degrees. The ${ }^{1} \mathrm{H}$ - and ${ }^{13} \mathrm{C}-\mathrm{NMR}$ spectra (Table 2) of $\mathbf{3}$ were similar to those of chamaejasmine [5] except a methoxy signal $\left[\delta_{\mathrm{H}} 3.79\left(3 \mathrm{H}, \mathrm{s}, \mathrm{OCH}_{3}-4^{\prime}\right), \delta_{\mathrm{C}} 159.6\left(\mathrm{C}-4^{\prime}\right)\right]$ in $\mathbf{3}$ was in place of a hydroxy group at C-4' in chamaejasmine. Thus the planar structure of $\mathbf{3}$ was determined as 3-(5,7-dihydroxy2-(4-hydroxyphenyl)-4-oxochroman-3-yl)-5,7-dihydroxy-2-(4-methoxyphenyl)-2,3-dihydrochromen-4-one. The relation configurations at $\mathrm{C}-2 / \mathrm{C}-3$ and $\mathrm{C}-3 " / \mathrm{C}-2 "$ positions were decided as trans-trans by comparison of $J$ values of $\mathrm{H}-2 / \mathrm{H}-3$ with $12.0 \mathrm{~Hz}$ and $\mathrm{H}-3 " / \mathrm{H}-2 "$ with $12.0 \mathrm{~Hz}$, and no correlations between H-3/H-2, H-3"/H-2" were observed. Additionally, H-3 and H-3' $\left(\delta_{\mathrm{H}} 2.60(2 \mathrm{H}, \mathrm{dd}, J=18.0\right.$, $12.0 \mathrm{~Hz})$ ) with same chemical shift supported the H-3 and H-3' being at same side. Referring to chamaejasmine [5] with $[\alpha]_{\mathrm{D}}-61.2(c 0.49, \mathrm{MeOH})$, compound 3 with dextrorotatory optical activity, $[\alpha]_{\mathrm{D}}+53.1(c 0.058, \mathrm{MeOH})$, indicated 3 is an enantiomer of chamaejasmine. According to the above evidence, the structure of $\mathbf{3}$ was elucidated as to be $(2 R, 3 S)-3-((2 " R, 3 " S)-5$ ",7"-dihydroxy-2"-(4"'hydroxyl-phenyl)-4-oxochroman-3-yl)-5,7-dihydroxy-2-(4-methoxyphenyl)-2,3-dihydrochromen-4-one, named wikstaiwanone $\mathrm{C}$, which was further confirmed by HMQC, DEPT, NOESY and HMBC (Figure 2) techniques. 
Table 2. ${ }^{1} \mathrm{H}-\mathrm{NMR},{ }^{13} \mathrm{C}-\mathrm{NMR}$, and HMBC Data of Compound 3.

\begin{tabular}{|c|c|c|c|}
\hline \multirow[b]{2}{*}{ Position } & \multicolumn{3}{|c|}{$3^{\mathrm{a}}$} \\
\hline & $\delta_{\mathrm{H}}(J$ in $\mathrm{Hz})$ & $\delta_{\mathrm{C}}$ & HMBC \\
\hline 2 & $5.70(\mathrm{~d}, J=12.0 \mathrm{~Hz})$ & 82.3 & H-3, H-3", H-2', H-6' \\
\hline 3 & $2.60(\mathrm{dd}, J=12.0,18.0 \mathrm{~Hz})$ & 48.5 & $\mathrm{H}-3 "$ \\
\hline 4 & & 193.0 & $\mathrm{H}-3$ \\
\hline 5 & & 161.8 & H-6 \\
\hline 6 & 5.46 (br d) & 96.7 & $\mathrm{H}-8$ \\
\hline 7 & & 161.9 & $\mathrm{H}-8$ \\
\hline 8 & $5.54(\mathrm{~s})$ & 97.5 & H-6 \\
\hline 9 & & 163.5 & $\mathrm{H}-8$ \\
\hline 10 & & 99.0 & H-6, H-8 \\
\hline $1^{\prime}$ & & 128.9 & H-2, H-2', H-3', H-5', H-6' \\
\hline $2^{\prime}$ & $6.95(\mathrm{~d}, J=8.0 \mathrm{~Hz})$ & 129.1 & H-2, H-3', H-6' \\
\hline $3^{\prime}$ & $6.87(\mathrm{~d}, J=8.0 \mathrm{~Hz})$ & 113.8 & H-2', H-5', H-6' \\
\hline $4^{\prime}$ & & 159.6 & H-2, H-3', H-5', H-6', Ome \\
\hline $5^{\prime}$ & $6.87(\mathrm{~d}, J=8.0 \mathrm{~Hz})$ & 113.8 & H-2', H-3, H-6' \\
\hline $6^{\prime}$ & $6.95(\mathrm{~d}, J=8.0 \mathrm{~Hz})$ & 129.1 & H-2, H-2', H-5' \\
\hline $2^{\prime}$ & $5.64(\mathrm{~d}, J=12.0 \mathrm{~Hz})$ & 82.5 & H-3, H-3", H-2"', H-6"' \\
\hline $3^{\prime}$ & $2.60(\mathrm{dd}, J=12.0,18.0 \mathrm{~Hz})$ & 48.6 & $\mathrm{H}-3$ \\
\hline $4^{\prime \prime}$ & & 193.0 & H-3" \\
\hline $5^{\prime \prime}$ & & 161.8 & H-6" \\
\hline $6 "$ & $5.46(\mathrm{br} \mathrm{d})$ & 96.6 & H-8" \\
\hline $7^{\prime \prime}$ & & 161.9 & H-8" \\
\hline $8^{\prime \prime}$ & $5.54(\mathrm{~s})$ & 97.6 & H-6" \\
\hline 9" & & 163.5 & H-8" \\
\hline $10^{\prime \prime}$ & & 99.1 & H-6", H-8" \\
\hline $1 " '$ & & 127.1 & H-2", H-3"', H-5"' \\
\hline $2^{\prime \prime \prime}$ & $6.78(\mathrm{~d}, J=8.0 \mathrm{~Hz})$ & 128.9 & H-2", H-3"', H-6"' \\
\hline $3^{\prime \prime \prime}$ & $6.70(\mathrm{~d}, J=8.0 \mathrm{~Hz})$ & 115.3 & H-2"', H-5"' \\
\hline 4"' & & 158.0 & H-2"', H-3"', H-5"', H-6"' \\
\hline $5 " '$ & $6.70(\mathrm{~d}, J=8.0 \mathrm{~Hz})$ & 115.3 & H-3"', H-6"' \\
\hline 6"' & $6.78(\mathrm{~d}, J=8.0 \mathrm{~Hz})$ & 128.9 & H-2", H-2'", H-5"' \\
\hline $\mathrm{OMe}$ & $3.79(\mathrm{~s})$ & 55.1 & \\
\hline
\end{tabular}

\subsection{Antitubercular Activity}

The amount of sample isolated for 1-7 ranged from about 3 to $42 \mathrm{mg}$, although all compounds underwent structural characterizations, only Shikokianins B (4) and C (5) (42.3 mg and $35.7 \mathrm{mg}$ respectively) provided sufficient quantity for evaluating their in vitro antitubercular activity against M. tuberculosis $\mathrm{H}_{37} \mathrm{Rv}$ with the clinical used drug ethambutol (MIC $6.25 \mu \mathrm{g} / \mathrm{mL}$ ) as a positive control. Results showed that both 4 and 5 have MIC values of about $15 \mu \mathrm{g} / \mathrm{mL}$. 


\section{Experimental Section}

\subsection{General Experimental Procedures}

Optical rotations were measured on a polarimeter (JASCO, Japan), UV spectra were obtained with a Jasco V-530 UV/VIS spectrophotometer. IR spectroscopic data were recorded on a Genesis II FTIR spectrophotometer with $\mathrm{KBr}$ pellets. NMR spectra were obtained on a Varian Unity Plus 400 spectrometer (400 MHz for ${ }^{1} \mathrm{H}-\mathrm{NMR}, 100 \mathrm{MHz}$ for ${ }^{13} \mathrm{C}-\mathrm{NMR}$ ) and Varian Unity Inova 600 spectrometer (600 MHz for ${ }^{1} \mathrm{H}-\mathrm{NMR}, 150 \mathrm{MHz}$ for ${ }^{13} \mathrm{C}-\mathrm{NMR}$ ). Chemical shifts were reported with respect to acetone- $d_{6}$, methanol- $d_{4}$ or DMSO solvents. Low-resolution MS spectra were obtained with Micromass Trio-2000 GC/MS, VG Biotech Quattro 5022, and JEOL-JMS-HX 100 mass spectrometers. The HRMS spectra were recorded on JEOL JMS-SX102A GC/LC/MS and Finnigan MAT-95XL high-resolution mass spectrometers. Silica gel (70-230 and 230-400 mesh; Merck) and Spherical C18 $100 \AA$ reversed phase silica gel (RP-18; particle size 20-40 $\mu \mathrm{m}$; Silicycle) were used for column chromatography, and silica gel 60 F254 (Merck) and RP-18 F254S (Merck) were used for TLC and preparative TLC. Further purification was performed by HPLC (Hitachi; pump: L-2130; UV detector: L-2400).

\subsection{Plant Material}

Stems of W. taiwanensis were collected in May, 2008 at Mountain Goshifer, Pingtung County, and identified by Professor Ih-Sheng Chen. A voucher specimen (Chen 6163) has been deposited in the Herbarium of the College of Pharmacy, Kaohsiung Medical University, Kaohsiung, Taiwan.

\subsection{Extraction and Isolation}

Dried stems $(9.8 \mathrm{~kg})$ of $W$. taiwanensis were sliced to about $0.5 \mathrm{~cm}$ in length and extracted three times, each time for 8 hours, with cold $\mathrm{MeOH}$ at room temperature to yield a $\mathrm{MeOH}$ extract, which was partitioned between EtOAc: $\mathrm{H}_{2} \mathrm{O}(1: 1)$ to provide an EtOAc-soluble fraction (390 g). Both the aqueous and the EtOAc-soluble fractions were studies for their biological activities. The active EtOAc-soluble fraction (70 g) was subjected to Sephadex $\mathrm{LH}-20$ column with $\mathrm{CH}_{2} \mathrm{Cl}_{2}-\mathrm{MeOH}$ (1:1) to obtained 4 fractions (1-4). The bioactive fraction $3(24 \mathrm{~g})$ was chromatographed on Silica gel CC and eluted with a $\mathrm{CH}_{2} \mathrm{Cl}_{2}-\mathrm{MeOH}-\mathrm{H}_{2} \mathrm{O}$ gradient solvent system (50:3:1 to 6:4:1) to give fractions 3a-q. Fraction $3 \mathrm{~b}(1.17 \mathrm{~g})$ was subjected to a silica gel $\mathrm{CC}$ with $\mathrm{CH}_{2} \mathrm{Cl}_{2}$-EtOAc (15:1) to give 10 fractions (3b-1 to 3b-10). Fraction 3b-7 was subjected to MPLC and eluted with $\mathrm{CH}_{2} \mathrm{Cl}_{2}$-acetone (15:1) to give 5 (35.7 mg); Fraction 3b-8 was applied to MPLC eluting with $\mathrm{CH}_{2} \mathrm{Cl}_{2}-\mathrm{MeOH}$ (20:1) to give 6 $(8.3 \mathrm{mg})$; and Fraction 3b-9 was purified with MPLC $\left(\mathrm{RP}_{18}\right)$ eluting with $\mathrm{MeOH}-\mathrm{H}_{2} \mathrm{O}(2: 1)$ to give 4 (42.3 mg). Fraction 3e (2.56 g) was subjected to Sephadex LH-20 column and RP18 column successively to give $\mathbf{1}(3.8 \mathrm{mg}), \mathbf{2}(6 \mathrm{mg})$ and $\mathbf{7}(3 \mathrm{mg})$. Fraction $3 \mathrm{f}$ (708 $\mathrm{mg})$ was eluted with $\mathrm{MeOH}-\mathrm{H}_{2} \mathrm{O}(1: 2)$ over $\mathrm{RP}_{18}$ column chromatography, purified with Sephadex LH-20 $(\mathrm{MeOH})$ and ODS HPLC (254 nm, $250 \times 10 \mathrm{~mm}, 70 \% \mathrm{CH}_{3} \mathrm{CN}$ (aq.), $2.0 \mathrm{~mL} / \mathrm{min}$ ) to give 3 (12 mg).

Wikstaiwanone $A$ (1): $\mathrm{C}_{30} \mathrm{H}_{22} \mathrm{O}_{10}$; Pale yellowish amorphous powder; $[\alpha]_{\mathrm{D}}^{25}=-77.0^{\circ}(c=0.03, \mathrm{MeOH})$; UV (MeOH): 210 (4.69), 217 sh (4.68), 266 (4.29), 315 sh (3.98), 355 sh (4.00); IR $v_{\max }$ (KBr): 3450 
$(\mathrm{OH}), 1647(\mathrm{C}=\mathrm{O}) \mathrm{cm}^{-1}$; ESI-MS, $\mathrm{m} / z 565\left([\mathrm{M}+\mathrm{Na}]^{+}\right)$, HR-ESI-MS at $\mathrm{m} / z$ $565.1107\left([\mathrm{M}+\mathrm{Na}]^{+}\right.$, $\mathrm{C}_{30} \mathrm{H}_{22} \mathrm{O}_{10} \mathrm{Na}$, calc. 565.1111); ${ }^{1} \mathrm{H}-$ and ${ }^{13} \mathrm{C}-\mathrm{NMR}$ data, see Table 1.

Wikstaiwanone $B(2)$ : $\mathrm{C}_{30} \mathrm{H}_{22} \mathrm{O}_{10}$; Pale yellowish amorphous powder; $[\alpha]_{\mathrm{D}}^{24}=-23.3^{\circ}(c=0.03, \mathrm{MeOH})$; UV (MeOH): 202 (4.72), 207 (4.72), 225 sh (4.51), 264 (4.36), 313 sh (4.04), 348 sh (3.94); IR $v_{\max }$ $(\mathrm{KBr}): 3395(\mathrm{OH}), 1638(\mathrm{C}=\mathrm{O}) \mathrm{cm}^{-1}$; ESI-MS $\mathrm{m} / \mathrm{z} 565\left([\mathrm{M}+\mathrm{Na}]^{+}\right)$; HR-ESI-MS at $\mathrm{m} / \mathrm{z} 565.1114$ $\left([\mathrm{M}+\mathrm{Na}]^{+}, \mathrm{C}_{30} \mathrm{H}_{22} \mathrm{O}_{10} \mathrm{Na}\right.$, calc. 565.1111); ${ }^{1} \mathrm{H}-$ and ${ }^{13} \mathrm{C}-\mathrm{NMR}$ data, see Table 1.

Wikstaiwanone $C(3)$ : $\mathrm{C}_{31} \mathrm{H}_{24} \mathrm{O}_{10}$; Pale yellowish amorphous powder; $[\alpha]_{\mathrm{D}}^{25}=+53.1^{\circ}(c=0.058$, $\mathrm{MeOH})$; UV (MeOH): 212 (4.61), 230 sh (4.47), 294 (4.55), 330 sh (3.77); IR $v_{\max }$ (KBr): 3395 (OH), 1631, $1617(\mathrm{C}=\mathrm{O}) \mathrm{cm}^{-1}$; ESI-MS $\mathrm{m} / z 579\left([\mathrm{M}+\mathrm{Na}]^{+}\right)$; HR-ESI-MS at $\mathrm{m} / z \quad 579.1269\left([\mathrm{M}+\mathrm{Na}]^{+}\right.$, $\mathrm{C}_{31} \mathrm{H}_{24} \mathrm{O}_{10} \mathrm{Na}$, calc. 579.1267); ${ }^{1} \mathrm{H}$ - and ${ }^{13} \mathrm{C}$-NMR data, see Table 2.

\subsection{Antitubercular Activity Assay}

The in vitro antitubercular activity of each tested compound was evaluated using the Mycobacterium tuberculosis $\mathrm{H}_{37} \mathrm{Rv}$. Middlebrook $7 \mathrm{H} 10$ agar was used to determine the minimum inhibitory concentration (MIC) values as recommended by the proportion method [22]. Briefly, each test compound was added to Middlebrook $7 H 10$ agar supplemented with oleic acid-albumin-dextrose-catalase (OADC) at $50-56^{\circ}$ by serial dilution to yield a final concentrations of 100 to $0.8 \mu \mathrm{g} / \mathrm{mL}$. Ten milliliter samples of each concentration of test compound-containing medium, was dispensed into plastic quadrant Petri dishes. Several colonies of the test isolate of M. tuberculosis were selected to make a suspension with Middlebrook $7 H 10$ broth, and used as the initial inoculum. The inoculum of test isolate of $M$. tuberculosis was prepared by diluting the initial inoculum in Middlebrook 7 H1O broth until turbidity was reduced to that equivalent to that of the McFarland No. 1 standard. Final suspensions were prepared by adding Middlebrook 7 H1O broth, and preparing $10^{-2}$ dilutions of the standardized bacterial suspensions. After solidification of the Middlebrook 7 H1O medium, $33 \mu \mathrm{L}$ of the $10^{-2}$ dilution of the standardized bacterial suspensions was placed on each quadrant of the agar plates. The agar plates were then incubated at $35^{\circ}$ with $10 \% \mathrm{CO}_{2}$ for 2 weeks. The MIC is the lowest concentration of test compound that completely inhibited the growth of the test isolate of $M$. tuberculosis, as detected by the unaided eye.

\section{Conclusions}

Three new biflavonoids (1-3) together with four known compounds (4-7) were isolated from the stem of $W$. taiwanensis in this study. Several biflavonoids from Thymelaeaceae have been reported in a number of studies [11-18] and their biological activities evaluated [19-21]. Most of them contain C-3/C-3" linkage with a symmetrical structure [11-14], except for wikstrols [4], genkwanols and stelleranol [14-17]. Compounds 1 and 2 were constituted by a flavone and a flavan-3-ol moieties and connected by an unusual C-3/C-6" linkage, which was found for the first time in nature. The solubility in acetone of $\mathbf{1}$ and $\mathbf{2}$ is remarkably different, where $\mathbf{1}$ dissolved in acetone- $d_{6}$ slightly, $\mathbf{2}$ was readily soluble. Incidentally, their antitubercular properties have not previously been reported. In the study, compounds $\mathbf{4}$ and $\mathbf{5}$ were evaluated in this respect, and it was revealed that both have MIC values of $15 \mu \mathrm{g} / \mathrm{mL}$, which is of the same order as the MIC value for ethambutol, a clinically used drug for 
tuberculosis, i.e. of $6.25 \mu \mathrm{g} / \mathrm{mL}$. This indicated that the antitubercular activities of isolates from Thymelaeacea may be worth studying further.

\section{References}

1. The Burden of Disease Caused by TB. In Global Tuberculosis Control 2011; WHO: Geneva, Switzerland, 2011; p. 9.

2. Chang, F.Y. Taiwan Tuberculosis Control Report 2010; Centers for Disease Control: Taiwan, China, 2010; p. 4.

3. Niwa, M.; Jiang, P.F.; Hirata. Y. Two new C-3/C-3"-biflavanones from Wikstroemia sikokiana. Chem. Pharm. Bull. 1986, 34, 3631-3634.

4. Baba, K.; Taniguchi, M.; Kozawa, M. Three biflavonoids from Wikstroemia sikokiana. Phytochemistry 1994, 37, 879-883.

5. Niwa, M.; Otsuji, S.; Tatematsu, H.; Liu, G.Q.; Chen, X.F.; Hirata, Y. Stereostructures of two biflavanones from Stellera chamaejasme L. Chem. Pharm. Bull. 1986, 34, 3249-3251.

6. Parmar, V.S.; Kumar, A.; Bosht, K.S.; Mukherjee, S.; Prasad, A.K.; Sharma, S.K.; Wengel, J.; Olsen, C.E. Novel chemoselective de-esterification of esters of polyacetoxy aromatic acids by lipases. Tetrahedron 1997, 53, 2163-2176.

7. Takahashi, H.; Kubota, Y.; Miyazaki, H.;Onda, M. Heterocycles, XV. Enantioselective synthesis of chiral flavanonols and flavan-3,4-diols. Chem. Pharm. Bull. 1984, 32, 4852-4857.

8. Sethi, V.K.; Taneja, S.C.; Dhar, K.L.; Atal, C.K. (-)-Epiafzelechin 5-O- $\beta$-D-glucoside from Crataeva religiosa. Phytochemistry 1984, 23, 2402-2403.

9. Seto, R.; Nakamura, H.; Nanjo, F.; Hara, Y. Preparation of epimers of tea catechins by heat treatment. Biosci. Biotechnol. Biochem. 1997, 61, 1434-1439.

10. Ohmori, K.; Yano, T.; Suzuki, K. General synthesis of epi-series catechins and their 3-gallates: Reverse polarity strategy. Org. Biomol. Chem. 2010, 8, 2693-2696.

11. Yang, G.; Chen, D. Biflavanones, flavonoids, and coumarins from the roots of Stellera chamaejasme and their antiviral effect on hepatitis B virus. Chem. Biodivers. 2008, 5, 1419-1424.

12. Niwa, M.; Tatematsu, H.; Liu, G.Q.; Hirata, Y. Isolation and structures of two new C-3/C-3"-biflavanones, neochamaejasmin A and neochamaejasmin B. Chem. Lett. 1984, 539-542.

13. Liu, G.Q.; Tatematsu, H.; Kurokawa, M.; Niwa, M.; Hirata, Y. Novel C-3/C-3"-biflavanones from Stellera chamaejasme L. Chem. Pharm. Bull. 1984, 32, 362-365.

14. Yang, G.; Liao, Z.; Xu, Z.; Zhang, H.; Chen, D. Antimitotic and antifungal C-3/C-3"-biflavanones from Stellera chamaejasme. Chem. Pharm. Bull. 2005, 53, 776-779.

15. Feng, B.M.; Pei, Y.H.; Hua, H.M. A new biflavonoid from Stellera chmaejasme L. Chin. Chem. Lett. 2004, 15, 61-62.

16. Baba, K.; Taniguchi, M.; Kozawa, M. A spirobiflavonoid genkwanol B from Daphne genkwa. Phytochemistry 1992, 3, 975-980.

17. Baba, K.; Taniguchi, M.; Kozawa, M. A third spirobiflavonoid genkwanol C from Daphne genkwa. Phytochemistry 1993, 4, 863-867. 
18. Taniguchi, M.; Fujiwara, A.; Baba, K.; Wang, N.H. Two spirobiflavonoid from Daphne acutiloba. Phytochemistry 1998, 49, 913-916.

19. Nunome, S.; Ishiyama, A.; Kobayashi, M.; Otoguro, K.; Kiyohara, H.; Yamada, H.; Omura, S. In vitro antimalarial activity of biflavonoids from Wikstroemia indica. Planta Med. 2004, 70, 76-78.

20. Hu, K.; Kobayashi, H.; Dong, A.; Iwasaki, S.; Yao, X. Antifungal, antimitotic and anti HIV-1 agents from the roots of Wikstroemia indica. Planta Med. 2000, 66, 564-567.

21. Huang, W.; Zhang, X.; Wang, Y.; Ye, W.; Ooi, V.E.C.; Chung, H.Y.; Li, Y. Antiviral biflavonoids from Radix wikstroemiae (Liaogewanggen). Chin. Med. 2010, 5, 1-6.

22. Inderlied, C.B.; Nash, K.A. Antibiotics in Laboratory Medicine, 4th ed.; Williams \& Wilkins: Baltimore, MD, USA, 1996; pp. 127-175.

(C) 2012 by the authors; licensee MDPI, Basel, Switzerland. This article is an open access article distributed under the terms and conditions of the Creative Commons Attribution license (http://creativecommons.org/licenses/by/3.0/). 